\title{
The Radial Artery: Which Place in Coronary Operation?
}

\author{
Alessandro Parolari, MD, PhD, Patrizia Rubini, MD, Francesco Alamanni, MD, \\ Aldo Cannata, MD, Wang Xin, MD, Tiziano Gherli, MD, GianLuca Polvani, MD, \\ Thomas Toscano, MD, PhD, Marco Zanobini, MD, and Paolo Biglioli, MD \\ Department of Cardiac Surgery, University of Milan, Milan, and Department of Cardiac Surgery, University of Parma, Parma, \\ Italy
}

Previous long-term studies have shown unsatisfactory patency of saphenous vein grafts, compared with internal mammary artery grafts. Recently, the use of the radial artery as a coronary artery bypass graft has enjoyed a revival, on the basis of the belief that it will help improving long-term results of coronary operations. The recent report of encouraging 5-year patency rates, sup- ports its continued use as a bypass graft. In this paper, we review the current knowledge about the radial artery as a bypass graft, with special emphasis on the clinical results.

(Ann Thorac Surg 2000;69:1288-94)

(C) 2000 by The Society of Thoracic Surgeons
$\mathrm{T}$ here is increasing interest for the use of the radial artery (RA) as a coronary bypass graft. This is due to the well-documented long-term failure of greater saphenous vein conduits, which is the main cause of reoperation, and is even more common than the progression of native coronary disease [1]. On the other hand, the excellent results obtained with the left internal thoracic artery anastomosed to the left anterior descending coronary artery, which is patent in more than $90 \%$ of cases 10 years after operation [2], have added strength to the concept of arterial revascularization, reducing the number of patients presenting for reoperation. As the frequency of patients with already harvested or unavailable saphenous vein grafts has increased, alternative arterial conduits have been sought, and the RA is rapidly regaining popularity because of its length, diameter, and encouraging midterm results $[3,4]$. The aim of this paper is to review the data about RA as a coronary bypass graft.

\section{Historical Note}

The use of the RA as a graft for coronary revascularization was first introduced in 1975 by Carpentier and associates [5], but at that time, the experience was disappointing because of the high rate of graft failure $[6,7]$. This failure was probably due both to the unavailability of antispasmodic drugs, and to the harvest techniques since the role of the preservation of the endothelial function during harvest was unknown at that time [8].

The use of the RA as coronary graft was proposed again in 1992 by Acar and colleagues [9], after the casual finding that some of the grafts implanted in 1972 were

Address reprint requests to Dr Parolari, Department of Cardiac Surgery, University of Milan, Centro Cardiologico, Fondazione I Monzino IRCCS, Via Parea, 4, 20138, Milan, Italy; e-mail: aparolari@cardiologicomonzino. it. still patent 15 years later. Encouraging early patency rates were obtained during this new era, and were ascribed to an improved harvesting technique, together with the use of calcium channel blockers or other vasodilators to prevent perioperative spasm of the graft [10-12]. These reports led many other groups to reassess the role of this conduit in coronary bypass procedures.

\section{Anatomy, Suitability for Harvest, and Pathology of the RA}

The RA arises from the brachial artery bifurcation, below the elbow, at the radial tuberosity, and is the more direct continuation of the brachial artery. The other branch of the brachial artery bifurcation, the ulnar artery, which is usually of greater size, takes off at almost a right angle from the parent vessel.

The proximal RA courses underneath the muscle belly of the brachioradialis muscle, and then progressively leaves the lower surface of the muscle, running beneath the antebrachial fascia, between the brachioradialis muscle and the flexor carpi radialis muscle or the flexor carpi radialis tendon. In this area, care has to be taken to spare the lateral antebrachial cutaneous nerve, a branch of muscolocutaneous nerve which lies over the belly of the brachioradial muscle, to avoid postoperative paresthesias to the radial aspect of the volar forearm [13].

The intermediate portion of the RA lies close to the superficial branch of the radial nerve, which lies under the brachioradialis muscle. This nerve must be spared in order to avoid postoperative paresthesias to the thumb and the dorsum of the hand [13]. Near the wrist, the RA becomes superficial, lying anterior to the radius and pronator quadratus muscle, between the tendons of the brachoradialis and the flexor carp radialis muscles.

From its more distal portion, the RA has many 
branches, which anastomose with similar branches of the ulnar artery, providing the vascularization of the hand: (1) the carpal palmar branch anastomoses with a similar branch of the ulnar artery [14]; (2) the superficial palmar branch, together with the main trunk of the ulnar artery, forms the superficial palmar arch, which gives four common digital palmar arteries that bifurcate in proper digital palmar arteries. This arch has a dominant ulnar supply and a small radial end that may be absent in some cases [14]; (3) the dorsal carpal branch, with a similar ulnar branch, forms the dorsal carpal arch, and from this arch, the dorsal metacarpal arteries that anastomose with the deep palmar arch and the corresponding palmar metacarpal arteries arise by perforating branches. Subsequently the dorsal metacarpal arteries bifurcate in the dorsal digital arteries [14]; and (4) the termination of the RA itself anastomoses with the deep palmar branch of the ulnar artery to form the deep palmar arch. This arch has a dominant radial supply, and is slightly more proximal than the superficial arch, lying just beyond the basis of the metacarpals. From its convexity arise the palmar metacarpal arteries that anastomose with the corresponding common digital palmar arteries (superficial arch), and with dorsal metacarpal arteries (dorsal carpal arch) [14].

The rich intercommunication among the branches of the deep, superficial, and dorsal carpal arches allows the vascularization of the hand, in case of RA harvest at the forearm. Various reports on surgical management of forearm vascular trauma suggest that one functional artery, distal to the elbow, is enough for limb viability and vascular function $[15,16]$.

In fact, the harvest of the RA, which usually begins proximally after the radial recurrent branch, and terminates distally before the origin of the superficial palmar branch, in order to preserve as much collateral circulation as possible [17], is rarely a cause of hand ischemia. This is because the numerous anastomoses between the superficial and deep palmar arches, and dorsal carpal arch, can supplement small or missing branches of the others.

Only the absence, hypoplasia, or atrophy of the ulnar artery, which are rare findings [14, 18], contraindicate RA harvest, even if in these cases, a persistent median or a common interosseous or anterior interosseous artery may supplement or replace the ulnar artery, and may originate the palmar superficial arch or the digital arteries.

It is however, mandatory to assess the adequacy of the ulnar collateral circulation to the hand, before RA harvest. The up-to-date methods employed, include the Allen test [19] and modifications [20, 21], static and dynamic Doppler testing [22], direct digit pressure measurement during RA compression [23], and oxymetric plethysmography, together with the computation of a perfusion index [24]. Concerns with the adequacy of forearm collateral circulation, raised by the preoperative testing method, have excluded RA harvest unilaterally in $5 \%$ [12] to $11.6 \%$ [20], and bilaterally in 5\% [20] to $6.4 \%$ [24] of patients who are candidates for RA harvest.
In addition, sometimes the Allen test can be falsely normal, due to the presence of a high origin of the superficial palmar branch, or of an anomalous anterior interosseous artery. In these cases, it is cautious to perform an intraoperative Allen test, with the occlusion of these branches before ligating them [25].

Another anatomical feature, which must be considered when harvesting the RA, is that in about $15 \%$ of extremities, the RA may show a high origin, between the axilla and the elbow [18]. In these cases, RA course in the forearm can be more superficial, between the forearm muscles or in the subcutaneous tissue [14], and there is the chance of damage to the median nerve, which in case of origin of the RA directly from the axillary artery, can be immediately deep to the RA in the cubital fossa [18].

With regard to the anatomopathological features, the average RA length suitable for bypass varies between 18 and $22 \mathrm{~cm}$, and its inner diameter varies between 2 and $3 \mathrm{~mm}$ [26-28]. The RA is a thick-walled muscular artery. The intima has one layer of endothelial cells beneath, where multiple layers of subendothelial cells, and small amount of myocytes, are present. The internal elastica lamina has multiple fenestrations, and the media is constituted by many leiomyocytes, elastic and collagen fibers, fibroblasts, and rare macrophages. The external elastic lamina is less individualized than the internal lamina. Some evidence suggests that the vasa vasorum, nerves, and lymphatic vessels are confined to the adventitia, and do not join the medial layer within the structure of the adventitia [29], while others describe vasa vasorum penetration into RA media. This may theoretically cause some degree of hypoxia after the RA harvest [30].

With respect to the internal thoracic artery, the RA is a greater in size, has a thicker wall, and a higher density of muscle cells with the same amount of elastic tissue in its media [27]. Moreover, in the RA, the myocytes are organized in to multiple tight layers, while in the internal thoracic artery, the muscle cells are less organized and irregular in shape, and this, together with the wider thickness of the media, may at least in part explain the propensity of the RA to spasm [29].

Finally, it has been reported that the RA has a low prevalence of atherosclerosis [31]. However, comparative studies among arterial conduits used in myocardial revascularization have shown that the RA has a slightly higher degree of atherosclerosis than the internal thoracic artery, which also seems to be more resistant to the development of atherosclerosis, in the presence of vascular disease risk factors [29, 32, 33]. This slightly higher propensity of the RA to atherosclerosis usually does not impair RA flow, because of its relatively large diameter. Moreover, the RA is more subject to the chance of previous iatrogenous vascular trauma. The inability to use the RA because of severe calcification of this artery, or chronic dissection of the RA from prior cannulation, is a relatively rare event, occuring in only about $1 \%$ to $2 \%$ of candidates for RA harvest [34]. 
Table 1. Antispasmodic Drug Regimens for Radial Artery Graft Operation

\begin{tabular}{|c|c|c|c|}
\hline Drug & Loading Dose & Maintenance Dose & Reference \\
\hline \multirow[t]{3}{*}{ Diltiazem } & 0.15 to $0.25 \mathrm{mg} / \mathrm{kg}$ & $1 \mu \mathrm{g} / \mathrm{kg} / \mathrm{min}$, until able to take oral medications & [9] \\
\hline & 0.10 to $0.15 \mathrm{mg} / \mathrm{kg}$ & 0.25 to $0.50 \mu \mathrm{g} / \mathrm{kg} / \mathrm{min}$, until able to take oral medications & [24] \\
\hline & & $4 \mathrm{mg} /$ hour after aorta unclamping, until the 1 st postoperative day & [12] \\
\hline Milrinone & $\begin{array}{l}25 \mu \mathrm{g} / \mathrm{kg} \text { after aorta } \\
\text { unclamping }\end{array}$ & $0.2 \mu \mathrm{g} / \mathrm{kg} / \mathrm{min}$, until extubation & [25] \\
\hline Nifedipine & & $10 \mathrm{mg}$ every 6 hours sublingually for 24 hours, then $30 \mathrm{mg}$ orally & [41] \\
\hline Nitroglycerin & & 0.5 to $1.0 \mu \mathrm{g} / \mathrm{kg} / \mathrm{min}$ for 24 hours & [34] \\
\hline
\end{tabular}

\section{Biology and Spasm of the RA}

It is well-known that the biological features of the grafts, usually employed in coronary operation, may affect their long-term performance, in particular the endothelial function, which may sensibly affect the patency rate [8].

Early reports emphasized the high propensity of the RA to spasm [35], even though this phenomenon has also been reported in other arterial grafts, and the real incidence in the various conduits is still debated [36, 37]. Spasm has also been described in greater saphenous veins as well [38]. There are different hypotheses regarding the mechanisms underlying arterial graft and RA spasm, varying from endothelial trauma related to harvest [39], impaired vasomotor function due to coexistent systemic disease [39], and differing arterial graft endothelial function properties [40]. The advent of less traumatic RA harvesting techniques has significantly reduced the chance of endothelial trauma to this graft. It is commonly agreed upon that RA harvest must be performed with gentle mobilization of the RA, with light tractions, minimal touch, and minimal diathermy. Mechanical or hydrostatical dilation of the graft should be avoided, and the RA should only be flushed with a mixture of heparinized blood and papaverine [13, 24, 25].

The propensity of the RA to spasm has greatly been reduced using both topically and systemically different categories of vasodilators, including calcium channel blockers [9, 13, 41], papaverine [42], the phosphodiesterase inhibitor milrinone [25], and drug mixtures such as verapamil and nitroglycerin [43], or verapamil and papaverine [28]. Recent experimental evidence suggests that diltiazem and verapamil may have little effect in preventing both receptor-dependent and receptorindependent RA contractions, while organic nitrates and nifedipine seem to be more effective in inhibiting and reversing RA contractions [44]. Table 1 reports some of the intravenous antispasmodic drug administration protocols currently adopted.

It has recently been shown that adenoviral-mediated gene transfer, causing overexpression of nitric oxide synthase in human RAs, can minimize RA vasospasm through the inhibition of both voltage-dependent and receptor-dependent pathways [44], suggesting a possible future clinical application of gene therapy in the prevention of RA spasm.

Concern still exists however, for the theoretical possibility of RA spasm, and for that reason various studies have focused on the biological properties of this conduit in order to investigate the basis of this phenomenon.

It has been shown that the endothelial function of the $\mathrm{RA}$, as it releases endothelium-derived relaxing factors in response to endogenous and exogenous agents, is similar to that of other arteries. Significant basal and stimulated nitric oxide release have been reported in vivo [45], as well as maximal relaxation of the RA after acetylcholine administration [46]. Some comparative studies have shown that both endothelium-dependent and endothelium-independent vasorelaxation were similar to that of the internal thoracic artery [47], and that sensitivity to vasoconstricting agents like norepinephrine and serotonin was also similar [36].

On the other hand, it has been shown that, despite similar endothelial function, the RA can develop significantly higher maximal contractile force to vasoconstricting agents such as norepinephrine, serotonin, endothelin-I, and angiotensin II [36, 47], or to depolarizing agents such as potassium, with respect to the internal thoracic artery. This can be explained by the more muscular nature of this graft, which has a considerably thicker media, with respect to internal thoracic, gastroepiploic, and epigastric arteries, which are the usual conduits for arterial myocardial revascularization [29].

From the aforementioned data, it is suggested that the differences between the RA and internal thoracic artery are mainly related to histological features, and in particular, to the muscle cell population of the media and intima. This may affect the contractile properties of the graft, while the endothelial function seems to be very similar to that of the internal thoracic artery, and could be the basis for a more than satisfactory long-term patency. Because of these features, modulation of the RA graft with antispasmodic drugs of the RA graft contractile properties seems to be mandatory, especially in the early perioperative period, in order to avoid perioperative spasm, and possible failure of the graft.

\section{Review of Recent Clinical Experience Concerning the Use of the RA as a Bypass Graft}

We have reviewed recent use of the RA as coronary artery bypass graft by analyzing papers published in Medline-indexed journals between 1992 and 1998, in order to summarize current knowledge of conduit, with 
Table 2. Anastomotic Sites of Radial Artery Graft

\begin{tabular}{|c|c|c|c|c|c|c|c|}
\hline Year & Author & Patients & RA Grafts ${ }^{a}$ & $\begin{array}{c}\text { Distal } \\
\text { Anastomoses }^{\mathrm{b}}\end{array}$ & LAD & $C X$ & RCA \\
\hline 1992 & Acar [9] & 104 & $122(1,2)$ & $122(1,2)$ & $36(29.5 \%)$ & $59(48.4 \%)$ & $27(22.1 \%)$ \\
\hline 1993 & Acar [55] & 158 & $189(1,2)$ & $189(1,2)$ & $49(25.9 \%)$ & $93(49.2 \%)$ & $47(24.9 \%)$ \\
\hline 1993 & Hoffman [56] & 46 & $46(1,0)$ & $46(1,0)$ & $11(23.9 \%)$ & $22(47.8 \%)$ & $13(28.3 \%)$ \\
\hline 1995 & Calafiore [12] & $?$ & $161(1,1)$ & $188(1,3)$ & $32(25.0 \%)$ & $122(64.9 \%)$ & $34(10.1 \%)$ \\
\hline 1995 & Calafiore [53] & 148 & $152(1,0)$ & $184(1,2)$ & $32(17.4 \%)$ & $113(61.4 \%)$ & $39(21.2 \%)$ \\
\hline 1995 & Dietl [42] & 165 & $166(1,0)$ & $226(1,4)$ & $32(14.2 \%)$ & $178(78.8 \%)$ & $16(7.0 \%)$ \\
\hline 1995 & Fremes [28] & 50 & $51(1,0)$ & $51(1,0)$ & $5(9.8 \%)$ & $34(66.7 \%)$ & $12(23.5 \%)$ \\
\hline 1996 & Brodman [24] & 175 & $226(1,3)$ & $264(1,5)$ & $49(18.6 \%)$ & $146(55.3 \%)$ & $69(26.1 \%)$ \\
\hline 1996 & Brodman [51] & 197 & $261(1,3)$ & $311(1,6)$ & $55(17.7 \%)$ & $169(54.3 \%)$ & $87(28.0 \%)$ \\
\hline 1996 & Chen [10] & 60 & $94(1,6)$ & $94(1,6)$ & $28(29.8 \%)$ & $45(47.9 \%)$ & $21(22.3 \%)$ \\
\hline 1996 & Da Costa [40] & 83 & $84(1,0)$ & $99(1,2)$ & $32(32.3 \%)$ & $47(47.5 \%)$ & $20(20.2 \%)$ \\
\hline 1996 & Manasse [52] & 109 & $110(1,0)$ & $121(1,1)$ & $22(18.2 \%)$ & $74(61.2 \%)$ & $25(20.6 \%)$ \\
\hline 1998 & Acar [4] & 102 & $122(1,2)$ & NA & NA $(20.0 \%)$ & NA $(51.0 \%)$ & NA $(29.0 \%)$ \\
\hline 1998 & Possati [3] & 68 & $74(1,1)$ & $74(1,1)$ & $11(14.9 \%)$ & $43(58.1 \%)$ & $20(27.0 \%)$ \\
\hline 1998 & Tatoulis [34] & 261 & $522(2,0)$ & $594(2,3)$ & $50(8.4 \%)$ & $281(47.3 \%)$ & $263(44.3 \%)$ \\
\hline
\end{tabular}

a Average number of RA grafts per patient in parentheses. $\quad{ }^{b}$ Average number of distal anastomoses with the RA graft in parentheses.

$\mathrm{CX}=$ circumflex artery; $\quad \mathrm{LAD}=$ left anterior descending artery; $\quad \mathrm{NA}=$ not available; $\quad \mathrm{RA}=$ radial artery; $\quad \mathrm{RCA}=$ right coronary artery.

special emphasis on surgical strategies and postoperative results $[3,4,9-12,17,20,24,25,28,34,41,42,48-57]$.

\section{Operative Strategies}

The current indication in the use of the RA as a coronary graft is to supplement the internal thoracic artery in achieving complete arterial coronary revascularization [24], and, for that reason, the usual targets for this conduit are the right and circumflex arteries, and their branches (Table 2). Less frequently, the RA is used to revascularize some diagonal branches or the ramus intermedius. Finally, only when the mammary arteries are not suitable, the RA is anastomosed to the left anterior descending coronary artery $[3,4,24,34]$.

The majority of groups perform the RA harvest only on the nondominant upper limb, usually the left allowing simultaneous harvest of the RA and of the left internal thoracic artery $[3,9,52]$. Other authors, however, show no reluctance to also harvest the RA from the dominant upper limb [17, 20], and some groups have already described routine bilateral harvest of the RA [24, 34].

Sometimes a RA of adequate length can be divided into two segments, in order to obtain two separate grafts $[9,20,24]$, or it can be used to perform multiple distal anastomoses in a sequential fashion [11, 50].

There is still some debate on how to locate the proximal anastomosis of the RA, even if, in most cases, the majority of the groups prefer to anastomose the RA to the ascending aorta $[9,11,34,42,52]$. There is a consistent group of surgeons who suggest that the optimal method for proximal anastomosis is to perform a composite arterial graft with the RA coming off the left internal thoracic artery $[12,17,50,53,54]$. However, as reported patency rates are similar in both cases, it is suggested that performing proximal anastomosis on the ascending aorta should be the preferred method, because it is less technically demanding with respect to composite arterial grafting. In some selected cases, the RA can also be proximally anastomosed to a saphenous vein graft $[12,28$, $53,54]$, to the right internal thoracic artery $[12,17,53,54]$, to another radial artery graft [34], to the innominate artery [52], or to another coronary artery, as a coronary to coronary bypass graft $[58,59]$.

\section{Early Results}

Early average patency rate (within 6 months), and perfect patency rate of the RA are $98.1 \%$ (627 of 639) and $90.8 \%$ (474 of 522), respectively (Table 3 ).

The use of the RA in coronary operation does not seem to increase the rate of main postoperative complications, as reported in Table 4 . Briefly, myocardial infarction rates in the published series vary between $0 \%[17,20]$ and $4.0 \%$

Table 3. Early Patency Rates of the Radial Artery Graft

\begin{tabular}{llccc}
\hline Year & \multicolumn{1}{c}{ Author } & $\begin{array}{c}\text { RA } \\
\text { Grafts } \\
\text { Assessed }\end{array}$ & $\begin{array}{c}\text { Patent } \\
\text { RA } \\
\text { Grafts }\end{array}$ & $\begin{array}{c}\text { Perfectly } \\
\text { Patent } \\
\text { RA Grafts }\end{array}$ \\
\hline 1992 & Acar [9] & 56 & $56(100 \%)$ & $50(89.3 \%)$ \\
1993 & Acar [55] & 73 & $73(100 \%)$ & $67(91.8 \%)$ \\
1993 & Hoffman [56] & 46 & $46(100 \%)$ & $42(91.3 \%)$ \\
1994 & Calafiore [54] & 26 & $26(100 \%)$ & $26(100 \%)$ \\
1995 & Calafiore [12] & 76 & $75(98.7 \%)$ & NA \\
1995 & Calafiore [53] & 41 & $41(100 \%)$ & NA \\
1996 & Barner [17] & 13 & $10(76.9 \%)$ & $10(76.9 \%)$ \\
1996 & Brodman [24] & 89 & $87(97.8 \%)$ & $86(96.6 \%)$ \\
1996 & Chen [10] & 94 & $90(95.7 \%)$ & $86(95.5 \%)$ \\
1996 & Da Costa [40] & 61 & $59(96.7 \%)$ & $53(86.9 \%)$ \\
1996 & Manasse [52] & 18 & $18(100 \%)$ & $11(61.1 \%)$ \\
1997 & Weinschelbaum & 46 & $46(100 \%)$ & $43(93.5 \%)$ \\
& [50] & & & \\
\hline
\end{tabular}

$\mathrm{NA}=$ not available; $\quad \mathrm{RA}=$ radial artery. 
Table 4. Perioperative Complications of Radial Artery Grafting

\begin{tabular}{|c|c|c|c|c|c|c|c|}
\hline Year & Author & Patients & $\begin{array}{l}\text { In-hospital } \\
\text { Death }\end{array}$ & AMI & $\begin{array}{l}\text { Low-Output } \\
\text { Syndrome }\end{array}$ & $\begin{array}{l}\text { Reexploration } \\
\text { for Bleeding }\end{array}$ & $\begin{array}{l}\text { Minor Hand } \\
\text { Complications }\end{array}$ \\
\hline 1992 & Acar et al [9] & 104 & $1(0.9 \%)$ & $2(1.9 \%)$ & $5(4.8 \%)$ & $0(0 \%)$ & $8(7.6 \%)$ \\
\hline 1993 & Acar et al [55] & 158 & $2(1.3 \%)$ & $3(1.8 \%)$ & $10(6.3 \%)$ & NA & $11(7.0 \%)$ \\
\hline 1995 & Calafiore et al [53] & 148 & $2(1.4 \%)$ & $3(2.0 \%)$ & $3(2.0 \%)$ & $2(1.4 \%)$ & $1(0.7 \%)$ \\
\hline 1995 & Dietl and Benoit [42] & 165 & $5(3.0 \%)$ & $9(5.5 \%)$ & NA & NA & $3(1.8 \%)$ \\
\hline 1995 & Fremes et al [28] & 50 & $0(0 \%)$ & $0(0 \%)$ & $3(6.5 \%)$ & $3(1.8 \%)$ & $0(0 \%)$ \\
\hline 1996 & Barner and Johnson [17] & 172 & $0(0 \%)$ & $5(2.9 \%)$ & $6(3.4 \%)$ & $2(1.2 \%)$ & NA \\
\hline 1996 & Barner [20] & 377 & $0(0.0 \%)$ & $9(2.4 \%)$ & $5(1.3 \%)$ & $5(1.3 \%)$ & $11(3.0 \%)$ \\
\hline 1996 & Brodman et al [24] & 175 & $3(1.7 \%)$ & $2(1.1 \%)$ & NA & NA & $7(4.2 \%)$ \\
\hline 1996 & Da Costa et al [11] & 83 & $4(4.8 \%)$ & $3(3.6 \%)$ & $6(7.2 \%)$ & $2(2.4 \%)$ & $3(3.6 \%)$ \\
\hline 1996 & Manasse et al [52] & 109 & $2(1.9 \%)$ & $4(3.6 \%)$ & $0(0 \%)$ & $2(1.9 \%)$ & $5(4.7 \%)$ \\
\hline 1997 & Buxton et al [25] & 757 & $6(0.9 \%)$ & $6(0.9 \%)$ & $7(0.9 \%)$ & NA & $0(0 \%)$ \\
\hline 1997 & Gurevitch et al [49] & 33 & $1(3.0 \%)$ & $1(3.0 \%)$ & $1(3.0 \%)$ & $0(0 \%)$ & $0(0 \%)$ \\
\hline 1997 & Shapira et al [61] & 138 & $0(0 \%)$ & $0(0 \%)$ & $1(0.7 \%)$ & $0(0 \%)$ & $6(4.0 \%)$ \\
\hline 1997 & Weinschelbaum et al [50] & 164 & $3(1.8 \%)$ & $3(1.8 \%)$ & $4(2.4 \%)$ & NA & $32(19.6 \%)$ \\
\hline 1998 & Sudhakar et al [48] & 200 & $2(1.0 \%)$ & $8(4.0 \%)$ & NA & NA & $6(3.0 \%)$ \\
\hline 1998 & Tatoulis et al [34] & 261 & $2(0.8 \%)$ & $2(0.8 \%)$ & NA & $1(0.4 \%)$ & $4(1.6 \%)$ \\
\hline
\end{tabular}

AMI = acute myocardial infarction; $\quad \mathrm{NA}=$ not available.

[48] to 5.5\% [42], and myocardial infarction has been reported in the territory of the RA graft in no more of one third of these cases. The rates of in-hospital mortality reported in the series, using the RA are within the usual range for primary coronary operation, ranging between $0.8 \%[34]$ and $3.0 \%[42,49]$ to $4.8 \%$ [11].

A recent paper from the University of Toronto has analyzed the outcomes in patients who underwent coronary artery bypass grafting between 1989 and 1996 at their institution. They retrospectively compared 2333 patients who underwent operation with the use of 1 arterial graft (internal thoracic artery), with patients who, during the same time period, received bilateral internal thoracic arteries $(n=378)$ or left internal thoracic artery plus the RA ( $n=171)$, documenting, within the limits of a retrospective nonrandomized study, that the use of two arterial grafts is associated with lower mortality and morbidity rates. Moreover, when assessing the outcomes of the two patient groups, receiving two arterial grafts (bilateral mammary grafts versus left internal thoracic artery plus RA), there was no difference in perioperative mortality or cardiac morbidity rates, despite an higher risk factor incidence in patients receiving a RA graft as a second arterial graft. Finally, patients who received the RA graft had a lower incidence of sternal wound infection, and a trend toward reduced transfusion requirements compared with patients who underwent operation with the use of bilateral thoracic arteries [41].

Complications related to RA harvest are usually very low, and postoperative acute hand ischemia after RA harvest is a rare event whichever method is used for the assessment of collateral circulation. In fact, most of the previous reports could not document a postoperative case of hand ischemia, and only 1 case of acute hand ischemia, due to congenital absence of the ulnar artery, has been described after harvest of the RA [60], to our knowledge.
In this surgical series, no cases of compartment syndrome were reported, and only 1 case of upper limb motor loss, due to surgical lesion of a forearm peripheral nerve, was reported [34]. The incidence of dysesthesias of the forearm and the hand, the most frequent upper limb complications, was under $10 \%[11,17,24,48,52]$ and, in most cases, these sensitive symptoms disappeared completely within days or weeks. The occurrence of forearm surgical wound infection was a rare event [42], as well as the development of forearm hematoma, which happened in less than $4 \%$ of patients $[34,42,48,50]$.

\section{Follow-up Studies}

The average angiographic RA graft patency rates at midterm (6 to 36 months) were $93.3 \%$ (280 of 300) for overall patency rates, and 78.8\% (186 of 233) for perfect patency rates (Table 5). Encouraging 5-year RA patency rates RA have recently been reported by two different

Table 5. Midterm Angiographic Studies of the Radial Artery Graft

\begin{tabular}{lccc}
\hline Year $\quad$ Author & $\begin{array}{c}\text { RA Grafts } \\
\text { Assessed }\end{array}$ & $\begin{array}{c}\text { Patent } \\
\text { RA Grafts }\end{array}$ & $\begin{array}{c}\text { Perfectly Patent } \\
\text { RA Grafts }\end{array}$ \\
\hline 1992 Acar et al [9] & 31 & $29(93.5 \%)$ & $28(90.3 \%)$ \\
1993 Acar et al [55] & 46 & $42(91.3 \%)$ & $41(89.1 \%)$ \\
1994 Calafiore et al [54] & 17 & $16(94.1 \%)$ & $16(94.1 \%)$ \\
1995 Calafiore et al [12] & 35 & $33(94.3 \%)$ & NA \\
1995 Calafiore et al [53] & 32 & $30(93.7 \%)$ & NA \\
1996 Da Costa et al [11] & 12 & $12(100 \%)$ & $12(100 \%)$ \\
1996 Manasse et al [52] & 57 & $55(96.5 \%)$ & $37(64.9 \%)$ \\
1998 Possati et al [3] & 48 & $42(87.5 \%)$ & $32(66.7 \%)$ \\
1998 Sudhakar et al [48] & 6 & $6(100 \%)$ & $6(100 \%)$ \\
1998 Tatoulis et al [34] & 16 & $15(93.7 \%)$ & $14(87.5 \%)$ \\
\hline
\end{tabular}

$\mathrm{NA}=$ not available; $\quad \mathrm{RA}=$ radial artery. 
groups, with overall patency rates of $84.4 \%$ [4] and $91.9 \%$ [3], respectively, and perfect patency rates of $82.8 \%$ [4] and $87.1 \%$ [3], respectively. Interestingly, both groups report that in a small percentage of cases, the midterm control showed a perfect angiographic result, whereas at short-term, a narrowing of the same RA graft was detected.

Finally, Possati and colleagues report that a Doppler study of the vascularization of the forearm, performed 5 years after operation, can document that removal of the RA could be completely compensated for by an anastomotic network of the ulnar artery in all patients. The only complication related to RA harvest, which was present at 5 years follow-up, was the presence of a very slight paresthesias to the hand in one fourth of patients, while three fourths of patients were completely asymptomatic [3].

\section{Comment}

The favorable results summarized in this review indicate that the RA can be used successfully in coronary operation, and is rapidly becoming the second choice for arterial grafting, after the internal thoracic artery, because of ease in dissection and handling and because of minor harvesting complications, which do not hinder forearm blood flow.

The collateral flow to the hand which is almost constantly furnished by the ulnar artery through the palmar arches, and the low incidence of atherosclerosis on the native vessel, support RA grafting within a large spectrum of age. Correct preoperative assessment of the adequacy of the ulnar collateral circulation is critical in avoiding ischemic complications to the forearm and the hand.

The use of the RA can help to expand complete arterial myocardial revascularizations, and moreover, its morphometric features allow it to reach virtually any coronary artery, to perform multiple distal anastomoses in sequential fashion, and sometimes to obtain two separate grafts by dividing one RA of adequate length. It has also been shown that it is possible to construct composite arterial conduits by proximally anastomosing the RA to the internal thoracic arteries.

The recent evidence regarding 5-years patency rates, supports the use of the RA as the second arterial graft, after the internal thoracic arteries, and we can expect that in future years further data will add strength to the use of the RA graft.

\footnotetext{
Alessandro Parolari thanks all of the staff surgeons of the Department of Thoracic and Cardiovascular Surgery of The Cleveland Clinic Foundation, Cleveland, $\mathrm{OH}$ and Craig R. Saunders, MD, Chief of the Department of Cardiothoracic Surgery, Beth Israel Medical Center, Newark, NJ, for their invaluable knowledge regarding use of the radial artery in coronary operation, during his stay at The Cleveland Clinic.
}

\section{References}

1. Salomon NW, Page US, Bigelow JC, Krause AH, Okies JE, Metzdorff MT. Reoperative coronary surgery. Comparative analysis of 6591 patients undergoing primary bypass and 508 patients undergoing reoperative coronary artery bypass. J Thorac Cardiovasc Surg 1990;100:250-9.

2. Loop FD, Lytle BW, Cosgrove DM, et al. Influence of the internal mammary artery graft on 10-year survival and other cardiac events. New Eng J Med 1986;314:1-6.

3. Possati GF, Gaudino M, Alessandrini F, et al. Midterm clinical and angiographic results of radial artery grafts used for myocardial revascularization. J Thorac Cardiovasc Surg 1998;116:1015-21.

4. Acar C, Ramsheyi A, Pagny JY, et al. The radial artery for coronary artery bypass grafting: clinical and angiographic results at five years. J Thorac Cardiovasc Surg 1998;116: 981-9.

5. Carpentier A, Guermonprez JL, Deloche A, Frechette C, DuBost $\mathrm{C}$. The aorta-to-coronary radial artery bypass graft. A technique avoiding pathological changes in grafts. Ann Thorac Surg 1973;16:111-21.

6. Fisk RL, Brooks CH, Callaghan JC, Dvorkin J. Experience with the radial artery graft for coronary artery bypass. Ann Thorac Surg 1976;21:513-8.

7. Curtis JJ, Stoney WS, Alford WC Jr, Burrus GR, Thomas CS Jr. Intimal hyperplasia. A cause of radial artery aortocoronary bypass graft failure. Ann Thorac Surg 1975;20:628-35.

8. Luscher TF. Vascular biology of coronary bypass grafts. Curr Opin Cardiol 1991;6:868-76.

9. Acar C, Jebara VA, Portoghese M, et al. Revival of the radial artery for coronary artery bypass grafting. Ann Thorac Surg 1992;54:652-9.

10. Chen AH, Nakao T, Brodman RF, et al. Early postoperative angiographic assessment of radial grafts used for coronary artery bypass grafting. J Thorac Cardiovasc Surg 1996;111: 1208-12.

11. Da Costa FD, da Costa IA, Poffo R, et al. Myocardial revascularization with the radial artery: a clinical and angiographic study. Ann Thorac Surg 1996;62:475-9.

12. Calafiore AM, Di Giammarco G, Teodori G, et al. Radial artery and inferior epigastric artery in composite grafts: improved midterm angiographic results. Ann Thorac Surg 1995;60:517-23.

13. Reyes AT, Frame R, Brodman RF. Technique for harvesting the radial artery as a coronary artery bypass graft. Ann Thorac Surg 1995;59:118-26.

14. Testut L, Latarjet A. Human anatomy. Paris: G Doin, 1929; 780-804.

15. Johnson M, Ford M, Johansen K. Radial or ulnar artery laceration. Repair or ligate? Arch Surg 1993;128:971-4.

16. Aftabuddin M, Islam N, Jafar MA, Haque E, Alimuzzaman M. Management of isolated radial or ulnar arteries at the forearm. J Trauma 1995;38:149-51.

17. Barner $\mathrm{HB}$, Johnson $\mathrm{SH}$. The radial artery as a T-graft for coronary revascularization. Operative Tech Card Thorac Surg 1996;1:117-36.

18. Funk GF, Valentino J, McCulloch TM, Graham SM, Hoffman HT. Anomalies of forearm vascular anatomy encountered during elevation of the radial forearm flap. Head Neck 1995; 17:284-92.

19. Fuhrman TM, Pippin WD, Talmage LA, Reilley TE. Evaluation of collateral circulation of the hand. J Clin Monitor 1992;8:28-32.

20. Barner HB. Defining the role of the radial artery. Semin Thorac Cardiovasc Surg 1996;8:3-9.

21. Johnson WH, Cromartie RS, Arrants JE, Wuamett JD, Holt JB. Simplified method for candidate selection for radial artery harvesting. Ann Thorac Surg 1998;65:1167.

22. Pola P, Serricchio M, Flore R, Manasse E, Favuzzi A, Possati GF. Safe removal of the radial artery for myocardial revascularization: a Doppler study to prevent ischemic complications to the hand. J Thorac Cardiovasc Surg 1996;112:737-44. 
23. Starnes SL, Wolk SW, Lampman RM, et al. Noninvasive evaluation of hand circulation before radial artery harvest for coronary artery bypass grafting. J Thorac Cardiovasc Surg 1999;117:261-6.

24. Brodman RF, Frame R, Camacho M, Hu E, Chen A, Hollinger I. Routine use of unilateral and bilateral radial arteries for coronary artery bypass graft surgery. J Am Coll Cardiol 1996; 28:959-63.

25. Buxton B, Windsor M, Komeda M, Gaer J, Fuller J, Liu J. How good is the radial artery as a bypass graft? Coronary Artery Dis 1997;8:225-33.

26. Shima H, Ohno K, Michi K, Egawa K, Takiguchi R. An anatomical study on the forearm vascular system. J Cranio Maxill Surg 1996;24:293-9.

27. Acar C, Jebara VA, Portoghese M, et al. Comparative anatomy and histology of the radial artery and the internal thoracic artery. Implication for coronary artery bypass. Surg Radiol Anat 1991;13:283-8.

28. Fremes SE, Christakis GT, Del Rizzo DF, et al. The technique of radial artery bypass grafting and early clinical results. J Cardiac Surg 1995;10:537-44.

29. Van Son JA, Smedts F, Vincent JG, van Lier HJ, Kubat K. Comparative anatomic studies of various arterial conduits for myocardial revascularization. J Thorac Cardiovasc Surg 1990;99:703-7.

30. Dresdale AR, Paone G, Silverman NA. Technical considerations in aortocoronary bypass grafting. [Review] Biomed Pharmacother 1990;44:359-64.

31. Ueyama K, Watanabe G, Kotoh K, et al. Pathological examination of radial artery-as a graft material for coronary artery bypass grafting. Nippon Kyobu Geka Gakkai Zasshi 1997; 45:1816-20.

32. Kaufer E, Factor SM, Frame R, Brodman RF. Pathology of the radial and internal thoracic arteries used as coronary artery bypass grafts. Ann Thorac Surg 1997;63:1118-22.

33. Sisto T. Atherosclerosis in internal mammary and related arteries. Scand J Thorac Cardiovasc Surg 1990;24:7-11.

34. Tatoulis J, Buxton BF, Fuller JA. Bilateral radial artery grafts in coronary reconstruction. Technique and early results in 261 patients. Ann Thorac Surg 1998;66:714-20.

35. Carpentier A. Discussion of Geha AS, Krone RJ, McCormick JR, Baue AE. Selection of coronary bypass: anatomic, physiological, and angiographic considerations of vein and mammary artery grafts. J Thorac Cardiovasc Surg 1975;70:414-31.

36. Chardigny C, Jebara VA, Acar C, et al. Vasoreactivity of the radial artery. Comparison with the internal mammary and gastroepiploic arteries with implications for coronary artery surgery. Circulation 1993;88(Suppl II):115-27.

37. Chamiot-Clerc P, Copie X, Renaud JF, Safar M, Girerd X. Comparative reactivity and mechanical properties of human isolated internal mammary and radial arteries. Cardiovasc Res 1998;37:811-9.

38. Baduini G, Marra S, Angelino PF. Sudden occlusion of a saphenous vein bypass graft relieved by direct injection of nitroglycerin. Catheter Cardio Diag 1981;7:87-95.

39. Sellke FW, Boyle EM Jr, Verrier ED. Endothelial cell injury in cardiovascular surgery: the pathophysiology of vasomotor dysfunction. Ann Thorac Surg 1996;62:1222-8.

40. He GW, Yang CQ, Starr A. Overview of the nature of vasoconstriction in arterial grafts for coronary operations. Ann Thorac Surg 1995;59:676-83.

41. Borger MA, Cohen G, Buth KJ, et al. Multiple arterial grafts. Radial versus right internal thoracic arteries. Circulation 1998;98(Suppl II):7-14.
42. Dietl CA, Benoit CH. Radial artery graft for coronary revascularization: technical considerations. Ann Thorac Surg 1995;60:102-9.

43. He GW, Yang CQ. Use of verapamil and nitroglycerin solution in preparation of radial artery for coronary grafting. Ann Thorac Surg 1996;61:610-4.

44. Cable DG, Caccitolo JA, Pearson PJ, et al. New approaches to prevention and treatment of radial artery graft vasospasm. Circulation 1998;98(Suppl II):15-22.

45. Joannides R, Haefeli WE, Linder L, et al. Nitric oxide is responsible for flow-dependent dilatation of human peripheral conduit arteries in vivo. Circulation 1995;91:1314-9.

46. Chester AH, Amrani M, Borland JAA. Vascular biology of the radial artery. Curr Opin Cardiol 1998;13:447-52.

47. He GW, Yang CQ. Radial artery has higher receptormediated contractility but similar endothelial function compared with mammary artery. Ann Thorac Surg 1997;63: 1346-52.

48. Sudhakar CB, Forman DL, Dewar ML, Shaw RK, Fusi S. Free radial artery grafts: surgical technique and results. Ann Plas Surg 1998;40:408-11.

49. Gurevitch J, Miller HI, Shapira I, et al. High-dose isosorbide dinitrate for myocardial revascularization with composite arterial grafts. Ann Thorac Surg 1997;63:382-7.

50. Weinschelbaum EE, Gabe ED, Macchia A, Smimmo R, Suarez LD. Total myocardial revascularization with arterial conduits: radial artery combined with internal thoracic arteries. J Thorac Cardiovasc Surg 1997;114:911-6.

51. Brodman RF, Frame R. The radial artery for myocardial revascularization. Operative Techniques Cardiac Thorac Surg 1996;1:137-46.

52. Manasse E, Sperti G, Suma H, et al. Use of the radial artery for myocardial revascularization. Ann Thorac Surg 1996;62: 1076-82.

53. Calafiore AM, Teodori G, Di Giammarco G, et al. Coronary revascularization with the radial artery: new interest for an old conduit. J Cardiac Surg 1995;10:140-6.

54. Calafiore AM, Di Giammarco G, Luciani N, Maddestra N, Di Nardo E, Angelini R. Composite arterial conduits for a wider arterial myocardial revascularization. Ann Thorac Surg 1994; 58:185-90.

55. Acar C, Farge A, Chardigny C, et al. Use of the radial artery for coronary artery bypass. A new experience after 20 years. Arch Mal Coeur Vaiss 1993;86:1683-9.

56. Hoffman O, Beyssen B, Pagny JY, Guermonprez JL, Gaux JC. Evaluation angiographique precoce des pontages coronaires par greffons arteriels. Arch Mal Coeur Vaiss 1993;86:1445-50.

57. Mortensen PE, Kjaergard HK. Koronar bypass-operation med a. radialis. Et alternativ hos patienter med varicer. Ugeskrift for Laeger 1998;160:4900-1.

58. Nottin R, Grinda JM, Anidjar S, Folliguet T, Detroux M. Coronary-coronary bypass graft: an arterial conduit-sparing procedure. J Thorac Cardiovasc Surg 1996;112:1223-30.

59. Tixier DB, Acar C, Carpentier AF. Coronary-coronary bypass using the radial artery. Ann Thorac Surg 1995;60:693-4.

60. Nunoo-Mensah J. An unexpected complication after harvesting of the radial artery for coronary artery bypass grafting. Ann Thorac Surg 1998;66:929-31.

61. Shapira OM, Alkon JD, Aldea GS, Madera F, Lazar HL, Shemin RJ. Clinical outcomes in patients undergoing coronary artery bypass grafting with preferred use of the radial artery. J Cardiac Surg 1997;12:381-8. 